\title{
Bag Dosing Unit
}

National Cancer Institute

\section{Source}

National Cancer Institute. Bag Dosing Unit. NCI Thesaurus. Code C48474.

A dosing unit equal to the amount of active ing redient(s) contained in a bag. 